\title{
COMMENTS
}

\section{Celebrity Names as Web Site Addresses: Extending the Domain of Publicity Rights to the Internet}

\author{
Deborah J. Ezer $\dagger$
}

Imagine that you are a celebrity, and when you type your name in as a domain name, www.yourname.com, you are brought to a web site that you neither created nor sanctioned. The site could be soliciting contributions for a charity you have never heard of, contain pornographic images, or even be auctioning off your name as a domain name while using the web site to advertise some other business. Each of these scenarios has occurred and has raised the ire of many celebrities attempting to protect one of the most valuable commodities that they control: the use of their names.

Barry Diller, head of USA Networks, Inc., has filed one of the first lawsuits claiming illegal use of a celebrity name as a domain name and demanding compensation for the unjust enrichment enjoyed by the men who attempted to sell his name to the highest bidder. Diller's suit relies on the doctrine of publicity rights and attempts to extend the scope of this well established theory of recovery to the Internet.' Other celebrities have similarly fallen victim to such opportunistic behavior. Household names like Brad Pitt, Madonna, and

$\dagger$ B.A. 1996, Yale University; J.D. 2000, The University of Chicago.

1 Barry Diller and his media company, USA Networks, Inc., initiated a suit on June 23, 1999 , against three men who allegedly tried to sell Diller's name as a domain name for $\$ 10$ million. Diller filed in New York Supreme Court, relying on New York's statutory publicity rights, among other claims. The three men, doing business as Thoughts and Cybermultimedia Inc., registered "barrydiller.com" as a domain name earlier that year without Diller's permission and offered it to web site visitors for $\$ 10$ million. The suit also claims the web site, www.cybermultimedia.com, used Diller's picture and the USA Networks trademark without his permission. Bloomberg, Barry Diller Sues Men Selling His Name, NY Post 34 (June 24, 1999); Troy Patterson and Will Lee, Monitor, Entertainment Weekly 12 (July 9,1999). 
John Tesh have recently become involved in disputes, attempting to gain control over web sites that use their names as domain names. ${ }^{2}$

At present, the published judicial decisions on domain name disputes generally involve business conflicts over the use of registered marks, and courts apply the law of trademark to govern the rights at issue. Trademark law regulates the use of registered marks, not unregistered names such as celebrity names. Thus, trademark law cannot be applied to these more recent disputes involving famous names, creating a hole in the fabric of the law.

On the other hand, the right of publicity allows celebrities and other well known public figures to control the commercial exploitation of their identities. It recognizes the inherent economic value in a celebrity name. The doctrine grants an individual the ability to prevent others from using his name when there is something so unique about the name that unauthorized use would create confusion as to what he has chosen to sponsor or to endorse. But because publicity rights laws are either established through state legislation or common law, and the use of a domain name on the Internet transcends state boundaries, it is not clear which law to apply. The Internet thus presents the unique and unsettled question of what rights and protections are available to a person's name, specifically when it is used as a domain name or "web address."

This Comment argues that courts should apply publicity rights law to celebrity names used as domain names. Part I traces the origins of publicity rights law and examines its development as an economic doctrine, establishing when the right of publicity exists, which states uphold this right, and to whom it applies. Part II considers the issues surrounding the extension of publicity rights to domain name disputes, and discusses both the policy rationales for this extension as well as the obstacles to applying the doctrine to these disputes. Part III argues that courts should apply publicity rights law to domain name disputes and demonstrates the feasibility of this proposal by elucidating characteristics, unique to domain names and publicity rights, that help overcome the obstacles. This Comment concludes that the application of publicity rights law to the Internet is a judicially practicable and desirable way to resolve celebrity domain name disputes.

2 Zack Stentz, Download by Law, Entertainment Weekly 81 (Feb 11, 2000); Steve Knopper, Pay To.Com: Bands Are Finding They Aren't Masters of Their Own Domains, Spin 60 (May 2000). 


\section{THE PUBLICITY RIGHTS DOCTRINE: COMMODIFYING THE CELEBRITY PERSONA}

The right of publicity exists as a statutory right in some states, ${ }^{3}$ a common law right in others, and not at all in a number of states. The

3 Seventeen states have enacted right of publicity statutes or right of privacy statutes that encompass a right of publicity. Cal Civ Code $\$ \S 3344-3344.1$ (West 1997 \& Supp 2000); Fla Stat Ann $\$ 540.08$ (West 1997 \& Supp 2000); 765 ILCS 1075/1 et seq (1999); Ind Code Ann \$\$ 32-131-1 to -20 (Burns 1999); Michie's Ky Rev Stat $\$ 391.170$ (Lexis 1999); Mass Ann Laws ch 214, § 3A (Lexis 1999); Neb Rev Stat \$ 20-202 (1997); Nev Rev Stat \$\$ 597.770-597.810 (1997); 1992 \& Supp 1999 NY Civ Rights Law $\S \S 50-51 ; 1996$ NY Gen Bus Laws § 397; 12 Okla Stat Ann \$ 1448-49 (West 1993 \& Supp 1999); 21 Okla Stat Ann $\$ \$ 839.1-839.3$ (West 1983 \& Supp 1999); RI Gen Laws $\$ \$ 9-1-28$ to -28.1 (1997); Tenn Code Ann $\$ \$ 47-25-1101$ to -1108 (1995); Tex Property Code Ann $\$ \$ 26.001-26.015$ (Vernon 2000); Utah Code Ann $\$ \$ 45-3-1$ to -6 (1998 \& Supp 1999) (limiting protection to false endorsements in advertising), Utah Code Ann \$ 76-9-407 (Lexis 1999) (establishing criminal penalty for similar offense); Va Code $\$ \$ 8.01-40,18.2-216.1$ (1996); Wash Rev Code Ann $\$ 63.60 .010$ et seq (West Supp 1999); Wis Stat Ann $\$ 895.50$ (West 1997).

Some of these states also recognize a common law right of publicity. See Slivinsky $v$ WatkinsJohnson Co, 221 Cal App 3d 799, 207 Cal Rptr 585, 589 (1990); Zim v Western Publishing Co, 573 F2d 1318, 1327-29 (5th Cir 1978) (Florida); Douglass v Hustler Magazine, Inc, 769 F2d 1128, 1138-39 (7th Cir 1985) (Illinois); Foster-Milburn Co v Chinn, 134 Ky 424, 120 SW 364, 366 (1909); Carson v National Bank of Commerce, 501 F2d 1082, 1084-85 (8th Cir 1974) (Nebraska); People for the Ethical Treatment of Animals v Berosini, Ltd, 111 Nev 615, 895 P2d 1269, 1283-85 (1995); Stephano v News Group Publications, Inc, 64 NY2d 174,474 NE2d 580, 584 (1984); McCormack v Oklahoma Publishing Co, 1980 Okla 98, 613 P2d 737, 739; Elvis Presley International Memorial Fund v Crowell, 733 SW2d 89, 97-99 (Tenn App 1987); National Bank of Commerce v Shaklee Corp, 503 F Supp 533, 539-41 (W D Tex 1980); Cox v Hatch, 761 P2d 556, 562-65 (Utah 1988); Hirsch v S.C. Johnson \& Sons, Inc, 90 Wis 2d 379, 280 NW2d 129, 132-33 (1979).

4 Twenty-four states recognize only a common law right of publicity or a common law right of privacy that encompasses a right of publicity. See Allison v Vintage Sports Plaques, 136 F3d 1443, 1447 (11th Cir 1998) (Alabama); Olan Mills, Inc v Dodd, 234 Ark 495, 353 SW2d 22, 23-24 (1962); Venturi v Savitt, Inc, 191 Conn 588, 468 A2d 933, 934 (1983); Slibeck v Union Oil Co of Califormia, 1986 Del Super LEXIS 1376, *3-5; Vassiliades v Garfinckel's Brooks Brothers, 492 A2d 580, 586-89 (DC 1985); Martin Luther King, Jr. Center for Social Change, Inc v American Heritage Products, Inc, 250 Ga 135, 296 SE2d 697, 697-700 (1982); Fergerstrom v Hawaiian Ocean View Estates, Inc, 50 Hawaii 374, 441 P2d 141, 144 (1968); Johnson v Boeing Airplane Co, 175 Kan 275, 262 P2d 808, 812 (1953); Prudhomme v Proctor \& Gamble Co, 800 F Supp 390, 395 (E D La 1992); Nelson v Times, 373 A2d 1221, 1223-24 (Me 1977); Lawrence v A.S. Abell Co, 299 Md 697, 475 A2d 448, 449-53 (1984); Carson v Here's Johnny Portable Toilets, Inc, 698 F2d 831, 834-36 (6th Cir 1983) (Michigan); Lake v Wal-Mart Stores, Inc, 582 NW2d 231, 233-35 (Minn 1998); Candebat v Flanagan, 487 S2d 207, 209-12 (Miss 1986); Haith v Model Cities Health Corp, 704 SW2d 684, 687-88 (Mo App 1986); Gilham v Burlington Northern, Inc, 514 F2d 660, 662-63 (9th Cir 1975) (Montana); Estate of Presley v Russen, 513 F Supp 1339, 1353-55 (D NJ 1981); Benally v Hundred Arrows Press, Inc, 614 F Supp 969 (D NM 1985); Flake v Greensboro News Co, 212 NC 780, 195 SE 55, 63 (1938); Reeves v United Artists Corp, 765 F2d 79, 80 (6th Cir 1985) (Ohio); Martinez v Democrat-Herald Publishing Co, 64 Or App 690, 669 P2d 818, 820 (1983); Gee v CBS, Inc, 471 F Supp 600, 661-62 (E D Pa 1979), affd, 612 F2d 572 (3d Cir 1979); Staruski v Continental Tel Co, 154 Vt 568,581 A2d 266, 268-69 (1990); Crump v Beckley Newspapers, Inc, $173 \mathrm{~W}$ Va 699,320 SE2d 70,81-89 (1984).

5 Those states that currently recognize neither a statutory right of publicity nor a common law right include Arizona, Colorado, Idaho, Iowa, New Hampshire, North Dakota, South Carolina, South Dakota, and Wyoming. 
right of publicity ${ }^{6}$ focuses specifically on the economic interests inherent in privacy rights. In other words, the publicity rights doctrine protects the right of an individual to control the commercial exploitation of his identity.

\section{A. The Development of the Publicity Rights Doctrine}

State courts started to view celebrity names as a property interest at the turn of the twentieth century. The process began with a 1903 New York statute that prohibited the use of a living person's name, portrait, or picture for "advertising purposes" or for "purposes of trade." The New York legislature enacted the statute to counter the Court of Appeals' decision in Roberson v Rochester Folding Box Co," which permitted the unauthorized use of a minor's photograph on a poster. Two years later, in Pavesich v New England Life Insurance Co, the Georgia Supreme Court held that the unauthorized use of a person's photograph in a testimonial advertisement was actionable as an invasion of privacy."

The plaintiffs in Roberson and Pavesich asserted claims that logically fit within the basic conception of privacy as the right to be let alone. In both cases, unknown people had been exposed to vast and unwanted publicity. Thus, courts could plausibly assimilate their claims of embarrassment or emotional distress within an emerging privacy rights framework.

Other courts soon began to apply this right to individuals who did not so easily fit into the traditional privacy rights mold. A New Jersey court, for example, explained its decision to enjoin the unauthorized use of Thomas Edison's name and picture on a medicine label utilizing the language of property:

\footnotetext{
6 Judge Jerome Frank first coined the term "right of publicity." Haelan Laboratories, Inc v Topps Chewing Gum, Inc, $202 \mathrm{~F} 2 \mathrm{~d} 866,868$ (2d Cir 1953). It has been classified as a subset of one of the four distinct torts that generally compose the common law right of privacy: (1) intrusion upon a person's seclusion; (2) public disclosures of embarrassing private facts; (3) publicity that places a person in a false light; and (4) commercial misappropriation of a person's identity. See J. Thomas McCarthy, The Rights of Publicity and Privacy $\S 1.5$ at 1-18 to -26 (West 1996); Restatement (Second) of Torts $\$$ 652A-652I (1977).

7 See, for example, Zacchini v Scripps-Howard Broadcasting Co, 433 US 562, 569 (1977); Estate of Presley, $513 \mathrm{~F}$ Supp at 1353. For a comprehensive review of publicity rights law, see McCarthy, The Rights of Publicity and Privacy (cited in note 6).

81903 NY Laws ch 132, § 1, codified as amended at NY Civ Rights Law $\S \S 50-51$ (McKinney 1999).

$9171 \mathrm{NY} 538,64 \mathrm{NE} 442,447$ (1902) (holding that there is no common law right of privacy in a case where a minor, whose photograph had been used without her consent on a widely distributed advertising poster, sued for protection of her image).

$10122 \mathrm{Ga} 190,50 \mathrm{SE} 68$ (1905).

11 Id at 81 . The plaintiff was a relatively unknown artist whose photograph was used without permission in a testimonial advertisement for life insurance.
} 
If a man's name be his own property, as no less an authority than the United States Supreme Court says, it is difficult to understand why the peculiar cast of one's features is not also one's property, and why its pecuniary value, if it has one, does not belong to its owner rather than to the person seeking to make an unauthorized use of it. ${ }^{12}$

This opinion contains one of the earliest judicial espousals of the view that unauthorized commercial appropriation of a person's identity infringes upon an economic interest. The New Jersey court regarded Edison's persona as a commodity that he controlled. The unauthorized use of Edison's persona damaged him by robbing him of the opportunity to market that commodity.

The early years of the twentieth century saw motion pictures and radio explode in popularity, and Hollywood quickly recognized the substantial economic value of celebrity personas. ${ }^{14}$ By the 1930 s, it was clear that if a celebrity only had a defensive right of privacy available to protect and to recover against unauthorized commercial uses of his identity after the injury had occurred, he would not be able to maximize the benefit from the publicity value of his name and likeness. Under traditional privacy law, once a celebrity chose to avail himself of the spotlight of fame, he was afforded a lower level of protection than an average citizen. Therefore, celebrity plaintiffs attempted to advance a theory of a property interest in one's name akin to the one supported in the Edison case.

In 1935, famous baseball players made a high-profile attempt to persuade the Fifth Circuit to accept this theory but were ultimately unsuccessful when the court rejected the theory in Hanna Manufacturing Co v Hillerich \& Bradsby Co. ${ }^{15}$ As Hanna demonstrated, celeb-

12 Edison v Edison Polyform and Manufacturing Co, 73 NJ Eq 136, 67 A 392, 394 (NJ 1907) (citation omitted).

13 Id at 394 (describing identity as property). See also Michael Madow, Private Ownership of Public Image: Popular Culture and Publicity Rights, 81 Cal L Rev 125, 156 (1993) (identifying the Edison opinion as one of the "earliest judicial statements [] that the interest infringed by unauthorized commercial appropriation of a public figure is economic").

14 Madow, $81 \mathrm{Cal} \mathrm{L}$ Rev at 160-64 (cited in note 13) (describing how the advent of movies and radio allowed fame to be based on image rather than accomplishment).

1578 F2d 763 (5th Cir 1935). In Hanna, the plaintiff ("Hillerich") had contracted with certain famous baseball players for the exclusive right to use their names, autographs, and photographs in connection with the sale and advertising of baseball bats. Hanna, a competing manufacturer, had no agreements with the players, yet copied Hillerich's product to the detail of stamping the surnames of the players on their bats. The Fifth Circuit rejected Hillerich's claim of property rights in the names of the players, stating that whether the rights of the players to prevent the unauthorized use of their names was a "personal" or a "property" right did not much matter, for the right was "not vendible in gross so as to pass from purchaser to purchaser unconnected with any trade or business." Id at 766 . The court balked at the idea of rewarding celebrity: "Fame is not merchandise. It would help neither sportsmanship nor business to uphold the sale of a famous name to the highest bidder as property." Id. 
rities could not rely on traditional privacy tort claims, given that movie stars and professional athletes had chosen to live in the public eye. They could not claim that being placed in the limelight caused emotional distress without seeming disingenuous and unconvincing. On the other hand, the argument that the uncompensated use of a celebrity's name or likeness was actionable did follow logically from celebrity status. ${ }^{16}$ Thus, celebrities needed something more than the existing right to privacy. They needed a new right that would protect against the unauthorized use of their name and likeness - the right of publicity.

In 1953, the Second Circuit took the lead and decisively recognized the right of publicity as an economic conception. In Haelan Laboratories, Inc v Topps Chewing Gum, Inc, the plaintiff, a chewing gum manufacturer, had contracted with certain well known baseball players for the exclusive right to use their photographs in selling its products. Subsequently, an independent party, Russell Publishing Company, which knew about Haelan's contracts, acquired similar grants from those same players. Russell assigned its rights to the defendant Topps, a competing chewing gum manufacturer, which then used the players' photographs in marketing its product. In response, Haelan sought an injunction on the ground that Topps's conduct violated its right of exclusive use. Topps asserted that the players possessed no legal interest in their photographs other than the right of privacy, which was a personal right and thus not assignable to third parties. ${ }^{18}$

The Second Circuit held for Haelan, stating frankly, "[I]n addition to and independent of that right of privacy (which in New York derives from statute), a man has a right in the publicity value of his photograph, i.e., the right to grant the exclusive privilege of publishing his picture."19 The court went on to state that this right could be licensed or assigned, and that the licensee or assignee could enforce it against third parties. The court defined the new right explicitly:

This right might be called a "right of publicity." For it is common knowledge that many prominent persons (especially actors and ball-players), far from having their feelings bruised through public exposure of their likenesses, would feel sorely deprived if they no longer received money for authorizing advertisements, popularizing their countenances, displayed in newspapers, magazines, busses, trains and subways. This right of publicity would usually

\footnotetext{
16 Madow, 81 Cal L Rev at 171-72 (cited in note 13).

17202 F2d 866 (2d Cir 1953).

18 Id at 867.

19 Id at 868 .
} 
yield them no money unless it could be made the subject of an exclusive grant which barred any other advertiser from using their pictures. ${ }^{20}$

The Second Circuit justified this new right solely on the ground that celebrities would "feel sorely deprived" if they were denied profits they could earn from their images. ${ }^{21}$ The court essentially transformed the celebrity personality into a commodity and allowed it to be traded in the market like any other product. Thus, by giving celebrity names legal protection, courts facilitated their growing commercial use.

Although Haelan was the first notable case to provide for the protection of celebrity names ${ }^{2}$ other courts followed the Second Circuit's lead in upholding the protection of musicians' names ${ }^{23}$ and other athletes' names. ${ }^{24}$ The right of publicity has since been expanded to protect nicknames and former names. For example, one court permitted a former football star known as "Crazylegs" to protect the use of that nickname..$^{25}$ A court also found that the nickname "The Greatest" identified Muhammud Ali and protected his right in its use..$^{26}$ Additionally, the court held basketball great Kareem Abdul-Jabaar not to have abandoned his right to protect his birth name, Lew Alcindor, by legally changing his name.

The 1970s and 1980s witnessed continued growth and expansion of publicity rights in many states, with the real boom occurring after the Supreme Court's first articulation of support for the right of publicity in Zacchini v Scripps-Howard Broadcasting $\mathrm{Co}^{28}$ In that case, Zacchini, a self-described "human cannonball" performer, brought an action against Scripps-Howard, a television broadcasting company, to recover damages suffered when Scripps-Howard filmed Zacchini's entire performance against his wishes and broadcast the footage on a

20 Id.

21 Id. See also Madow, 81 Cal L Rev at 173 (cited in note 13) (criticizing the Haelan court's failure to "explain why [celebrities' failure to profit from their images] should be cause for judicial concern").

22 Madow, 81 Cal L Rev at 172 (cited in note 13) (characterizing Haelan as a "decisive legal breakthrough").

23 Winterland Concessions v Creative Screen Designs, Ltd, 210 USPQ 6 (N D Ill 1980).

24 See Uhlaender v Henricksen, 316 F Supp 1277, 1282 (D Minn 1970) (recognizing baseball players' proprietary interest in their personalities); Palmer $v$ Schonhorn Enterprises, Inc, $96 \mathrm{NJ}$ Super 72,232 A2d 458, 462 (1967) (holding that golfers have a proprietary interest in their names and statisties despite purposeful public disclosure of such information).

25 Hirsch v S.C.Johnson \& Son, Inc, 90 Wis 2d 379, 280 NW2d 129, 137 (1979).

26 Ali v Playgirl, Inc, 447 F Supp 723 (S D NY 1978).

27 Abdul-Jabbar v General Motors Corp, 85 F3d 407 (9th Cir 1996) (refusing to recognize plaintiff's abandonment of his former name as a defense).

28433 US 562 (1977). 
news program. ${ }^{29}$ The Court rejected Scripps-Howard's First Amendment defense of newsworthiness, stating that " $[t]$ he broadcast of a film of petitioner's entire act poses a substantial threat to the economic value of that performance," ability to earn a living as an entertainer." The Court wrote that "the rationale for (protecting the right of publicity) is the straightforward one of preventing unjust enrichment by the theft of good will." ${ }^{32}$ After this decision, the view that individuals possess legal control over identifiable uses of their images gained "widespread acceptance in state law." Thus, the Court completed the conversion of control over the use of a celebrity's name into a property right.

\section{B. Applying the Publicity Rights Doctrine}

In order to institute a cause of action based on the right of publicity, a plaintiff must generally demonstrate that he owns an enforceable right in the identity involved, and that the defendant has infringed upon that right in some way-usually by an unauthorized commercial use of the identity. The basic elements of a publicity rights claim include showing that the defendant: (1) used the plaintiff's identity; (2) benefited from the use of the plaintiff's name or persona; (3) was not authorized to use the name or persona; and (4) injured the celebrity's value, commercial or otherwise. Pivotal issues that affect this analysis include whether the plaintiff can be identified from the defendant's unauthorized use of some aspect of the plaintiff's persona, whether the plaintiff is sufficiently well known to qualify for publicity rights protection, and whether the defendant's use of the plaintiff's

29 Id at 563.

30 Id at 575.

31 Id at 576.

32 Id, quoting Harry Kalven, Privacy in Tort Law: Were Warren and Brandeis Wrong?, $31 \mathrm{~L}$ \& Contemp Probs 326, 331 (1966).

33 Rochelle Cooper Dreyfuss, We Are Symbols and Inhabit Symbols, So Should We Be Paying Rent? Deconstructing the Lanham Act and Rights of Publicity, 20 Colum-VLA J L \& Arts 123,125-26 (1996).

34 See, for example, Cal Civ Code $\$ 3344$ (West 1997); NY Civ Rights Law §§ 50-51. For a general discussion, see McCarthy, The Rights of Publicity and Privacy, $\$ 3.1$ at 3-2 to -6 (cited in note 6); Restatement (Third) of Unfair Competition \$ 46 (1995) (stating that "one who appropriates the commercial value of a person's identity by using without consent the person's name, likeness, or other indicia or identity for purposes of trade is subject to liability"); William Prosser, Law of Torts $\$ 117$ at 804-07 (West 4th ed 1971); Bruce P. Keller and David H. Bernstein, The Right of Publicity: Towards a Federal Statute? in 1 PLI's Fourth Annual Institute for Intellectual Property Law 413, 430-36 (Practising Law Institute Course Handbook Series G-532 1998).

35 Bruce P. Keller and Craig Bloom, The Right of Publicity Versus the First Amendment, 17 Commun Lawyer 3, 3 (Summer 1999). See, for example, Eastwood v Superior Court, 149 Cal App 3d 409, 198 Cal Rptr 342, 347 (1983). 
identity is sufficiently distinct, such that it evokes an association with the plaintiff.

Since each state individually chooses whether to afford publicity rights and how broadly to extend those rights, the amount of protection afforded to celebrities will vary. For example, although on their face, New York and California's publicity rights laws are nearly identical, they are interpreted and applied quite differently." New York's right of publicity favors advertisers' freedom to use ideas and objects in the public domain, while California law favors the interests of celebrities at the expense of both legal certainty and advertisers' freedom.

Courts have tempered the right of publicity against intrusion upon others' fundamental rights. Accordingly, publicity rights are curtailed so as not to interfere with First Amendment liberties. ${ }^{39}$ The protection available in the right of publicity is limited to those individuals for whom there is something so unique about their name that its unauthorized use would create confusion as to what they have chosen to sponsor or endorse. ${ }^{40}$ While use of a celebrity name for financial gain is not protected, photographic images and material written on a celebrity for "newsworthy" purposes may be protected under the First Amendment."

36 Keller and Bernstein, The Right of Publicity at 433-34 (cited in note 34).

37 New York law provides that "[a]ny person whose name, portrait, picture or voice is used within this state for advertising purposes or for the purposes of trade without [ ] written consent ... may maintain an equitable action in the supreme court of this state against the person, firm or corporation so using his name, portrait, picture or voice, to prevent and restrain the use thereof; and may also sue and recover damages for any injuries sustained by reason of such use." NY Civ Rights Law \$ 51 .

California law provides that “[a]ny person who knowingly uses another's name, voice, signature, photograph, or likeness, in any manner, on or in products, merchandise, or goods, or for purposes of advertising or selling ... without such person's prior consent ... shall be liable for any damages sustained by the person or persons injured as a result thereof." Cal Civ Code $\S 3344(a)$.

38 Paul Cirino, Note, Advertisers, Celebrities, and Publicity Rights in New York and California, 39 NY L Sch L Rev 763, 770 (1994) (concluding that California law, which favors celebrities, is inferior to New York law, which favors advertisers).

39 See Peter L. Felcher and Edward L. Rubin, Privacy, Publicity, and the Portrayal of Real People by the Media, 88 Yale L J 1577, 1584-85 (1979) (arguing that the First Amendment controls the scope of privacy rights); James M. Treece, Commercial Exploitation of Names, Likenesses, and Personal Histories, 51 Tex L Rev 637, 668-71 (1973) (stating that when restricting advertising containing the name or likeness of an individual conflicts with the First Amendment, courts "must balance the public interest ... against the individual's interest in controlling advertising uses of his personality"); Keller and Bloom, 17 Commun Lawyer at 3 (cited in note 35) (noting the need for a First Amendment-publicity rights balance). See, for example, Cardtoons, L.C. v Major League Baseball Players Association, 95 F3d 959, 968-70 (10th Cir 1996) (finding defendant's First Amendment right to free expression trumped players' publicity rights in claim involving parody baseball trading cards).

40 See the articles cited in note 39.

41 See, for example, Montana $v$ San Jose Mercury News, Inc, 34 Cal App 4th 790, 40 Cal 


\section{ISSUES SURROUNDING THE EXTENSION OF PUBLICITY RIGHTS TO DOMAIN NAME DISPUTES}

The proposal to broaden the application of publicity rights to Internet domain names requires examining the policy rationales behind the publicity rights doctrine and its extension into other areas. This Part explains that the publicity rights doctrine is firmly grounded in economic, moral, and consumer protection theories and demonstrates why these rationales apply to the same (or an even greater) extent in the context of the Internet. Then, this Part discusses several obstacles to applying publicity rights doctrine to the Internet that complicate the analysis.

\section{A. Policy Rationales behind the Extension of the Publicity Rights Doctrine}

There are a number of reasons why a court might extend the publicity rights doctrine to the Internet. Courts created the doctrine to protect the property rights of the famous to control the use of their names and personas, and to prevent others from unjustly enriching themselves through the exploitation of a celebrity name or likeness. The policy arguments for the doctrine fall into three basic categories: economic, consumer protection, and moral. If these arguments apply equally to the Internet context, then there is good reason to afford the same protection for publicity rights in domain name disputes.

\section{Economic rationales for the doctrine.}

The most familiar version of the economic argument asserts that the right of publicity, like copyright law, provides incentives to stimulate creative exertion and achievement. ${ }^{42}$ The right of publicity is a tool for ensuring that a desired number of celebrities are produced. We choose to protect celebrities' rights to the commercial exploitation of their personas in order to encourage others to attain, or at least not discourage them from attaining, similar fame. It is not that the law aims to cultivate fame as an end, but rather that it respects the value society places on the achievement of fame from certain accomplish-

\footnotetext{
Rptr 2d 639,794 (1995) (holding that Mercury News had a First Amendment right to reprint and sell poster-size prints of professional football player Joe Montana that had previously appeared in newspaper on grounds that posters "reported newsworthy events"). See also note 39.

42 See, for example, David E. Shipley, Publicity Never Dies; It Just Fades Away: The Right of Publicity and Federal Preemption, 66 Cornell L Rev 673,681 (1981) (noting that "[p]rotecting the right of publicity provides incentive for performers to make the economic investments required to produce performances appealing to the public"); D. Scott Gurney, Note, Celebrities and the First Amendment: Broader Protections Against the Unauthorized Publication of Photographs, 61 Ind L J 697, 707 (1986) (arguing that the right of publicity serves to "maximize incentive to develop and maintain skills and talents that society finds appealing").
} 
ments or careers. In order to encourage continuing achievements in arts and culture, and to offer an incentive for people to strive to become the next "superstar," the law must ensure that those who invest time and money in accomplishing great cultural achievements earn a return on their investment in the form of the benefits of fame that come with these accomplishments.

One of the benefits of fame is the value of the celebrity name. Because society seeks to emulate its celebrities, endorsements are valuable commodities. If a celebrity persona is used too often, and its use does not accurately reflect the celebrity's choice, endorsements lose value because the public cannot distinguish which ones are genuine. In essence, allowing indiscriminate use of a celebrity name creates a problem where unauthorized individuals attempt to cash in on the celebrity's popularity or notoriety. This, in turn, dilutes the value of the celebrity name for future endorsements."

This dilution rationale supports extension of publicity rights to domain names: If celebrities are prevented from controlling their valuable commodities, their names, from being used as domain names, the value of that commodity is diluted in the physical world. This dilution then reduces the effectiveness of publicity rights, as it eliminates an incentive for individuals to invest in becoming celebrities.

One could argue that extending publicity rights to domain names might result in overprotection, since it grants exclusive rights over" a unique piece of Internet "property" to celebrities. However, the fact

43 See note 42.

44 Similarly, the law of trademarks recognizes this potential dilution and has applied it in the context of domain names. For example, a well known "cyber-pirate," Dennis Toeppen, registered plaintiff's trademark "Panavision" as a domain name, and used his web site to display an “aerial view of Pana, Illinois" Panavision International, LP v Toeppen, 945 F Supp 1296, 1300 (C D Cal 1996), affd, 141 F3d 1316 (9th Cir 1998). Toeppen demanded $\$ 13,000$ to give up use of the domain name. Id. In holding for the plaintiff, the court found that Toeppen diluted Panavision's trademark (here, its name) by causing confusion as to whether Panavision sponsored or endorsed his web site. Id at 1303-04. See also Toys ' $R$ ' Us $v$ Akkaoui, 40 USPQ2d 1836, 1837 (N D Cal 1996) (finding that an Internet site, "Adults R Us," running at "adultsrus.com," diluted the Toys ' $R$ ' Us trademarks, tarnishing them by "associating them with a line of sexual products that are inconsistent with the image Toys ' $R$ ' Us has striven to maintain for itself'); Hasbro, Inc $v$ Internet Entertainment Group, Ltd, 40 USPQ2d 1479, 1479 (W D Wash 1996) (granting plaintiff, owner of children's game "Candyland," an injunction to prevent defendant from operating pornographic web site at "candyland.com," thereby diluting and tarnishing plaintiff's mark).

Potential dilution in the publicity rights cases seems particularly salient when a celebrity's name (or a close spelling thereof) is used as a domain name for a pornographic or otherwise image-tarnishing web site. Domain names such as www.SharonStone.com or www.ReneeRusso.com (extra e added) have been registered and set up as pornographic web sites. Paul Bond, Whose .com is it Anyway?, The Hollywood Reporter (Oct 8, 1999). Many of these sites sell advertising space in the form of banner ads or receive compensation in other forms, such as a fixed rate per "hit" on the web site. Allowing such mercenaries to profit from celebrity property interests as well as mislead consumers would violate the policy concerns underlying publicity rights. 
that domain names create a discrete monopoly ${ }^{45}$ in cyberspace ${ }^{46}$ does not undermine the conclusion that applying publicity rights to domain names creates the proper incentives. Although the application of publicity rights means that people who share their names with celebrities may not be able to use their own names as domain names, this fits with the economic rationale for the publicity rights doctrine, which is preventing damage to the commercial value of a celebrity's identity. ${ }^{47}$ People who use a well known celebrity name as a domain name will be unjustly enriched because their web site will receive a lot of attention solely because they share their name with a celebrity. ${ }^{48}$ Further-

45 Only one person can register a domain name. Thus, even though multiple people can have the same name, only one person can own that domain name. While in trademark law two people may be allowed to have rights in the same mark as long as they are in different industries or significantly distant geographic locations, see Beverly W. Pattishall, David Craig Hilliard, and Joseph Nye Welch II, Trademarks and Unfair Competition, 271-84 (Matthew Bender 3d ed 1998), only one person can have that mark name as a domain name on the Internet. The structure of the Internet therefore creates more of a monopoly than in the trademark statutory scheme.

46 In order to understand the issues behind domain name disputes, one must first grasp the basic framework of the domain name system. Every computer connected to the World Wide Web ("WWW") network has both a domain name and Internet Protocol ("IP") that designate a WWW location analogous to the way addresses and telephone numbers direct us to streets and homes. The IP is a unique numeric address location that consists of four sets of numbers each between 1 and 255 , separated by periods, which indicate the network, subnetwork, and local computer accessible at that address. Andrew Terrett, $A$ Lawyers Introduction to the Internet, available online at <http://wwwlaw.ed.ac.uk/it-terr1.htm> (visited Oct 19, 1999); Danielle Weinberg Swartz, Comment, The Limitations of Trademark Law in Addressing Domain Name Disputes, 45 UCLA L Rev 1487,1489-90 (1998).

Because IP addresses are difficult to remember and easy to type incorrectly, the domain name system was established to serve as a more user-friendly equivalent. Swartz, Comment, 45 UCLA L Rev at 1489-90. Domain names, like IP addresses, are also separated by periods to indicate different network levels. The "top-level" domain, indicated by the last three letters on the far right of a domain name, corresponds to either the generic type of organization that registered the domain name or the geographical region of the organization. Because it was assumed that all domains would be located in the United States when the World Wide Web was first developed, the original hierarchy did not have a geographical domain for the United States. Thus, there are six top-level generic domain names: .com for company, org for organization, .gov for government, net for network organizations, .edu for academic institutions, and .mil for military networks. The top-level domain name generally identifies the type of owner using the address. Id. Commercial, for-profit organizations, or ".com" organizations, choose their own second-level designation; domain name owners frequently select trademarks or other well-known names or phrases to serve as their second-level designation. Id at 1490.

47 McCarthy, The Rights of Publicity and Privacy $\$ 3.1$ at 3-3 (cited in note 6).

48 This enrichment is obvious from the number of people who seek to register celebrity names as domain names. For instance, Rob Moritz of a group called the Friend to Friend Foundation has registered hundreds of domain names that consist of the monikers of famous people. He claims to be registering the names for the celebrities' protection, to prevent the pornographic web site scenario, and says he gives the domain names to the celebrities when they ask for them, hoping only for a donation large enough to cover the cost of the registration. However, Moritz has his web site configured such that, if one types in a domain name using a celebrity's name who has not yet claimed his web site, you are transported to Moritz's www.friendtofriend.com web site, from which he earns revenues through banner and other forms of advertisement. See Brenda Sandburg, The Name Game: As Fights Increasingly Erupt Over Internet Domain Names, 
more, there is less value to ordinary individuals' names because they are not in the public eye, and people are less likely to search for their web site by name.

\section{Consumer protection rationales for the doctrine.}

The right of publicity serves to protect consumers, as well as celebrities. The doctrine is similar in this way to the law of trademark, in that it seeks to protect consumers from deceptive trade practices and other market evils. ${ }^{50}$ In this view, publicity rights can be seen as a type of private regulation of advertising. ${ }^{\text {s. }}$ Because publicity rights law gives celebrities exclusive control over the use of their name, enforcement of those rights in the form of lawsuits against unauthorized use of their names or likenesses protects consumers from false or misleading endorsements. ${ }^{\text {s2 }}$ In addition, publicity rights law, like trademark law, "help[s] consumers make rational economic choices" by "promot[ing] the flow of useful information about commercial goods and services to the public [there]by ensuring that the public is not confused by a false implication that a particular celebrity has endorsed a particular good.".53

This rationale maintains its strength despite the fact that consumers may not themselves bring suit. Like the law of trademark, in which only registered mark holders possess the right of action, ${ }^{\text {st }}$ prohibiting publicity rights suits by consumers is an efficient mechanism that encourages meritorious suits, as celebrities possess the best incentives to protect that right, and discourages frivolous suits and an opening of the "flood gates" to the courthouse.

Broadening the right of publicity to apply to domain names would promote consumer protection goals, because consumers could at least be certain that a web site utilizing a celebrity's name as its domain name was sponsored, endorsed, or otherwise created by that celebrity. This would reduce some of the vast uncertainty in deter-

\footnotetext{
Will Lawyers Rake It In? Probably Not, 157 NJ L J 1077 (Sept 13,1999). See also note 44.

49 It may be interesting for the reader to note that organizations such as the Screen Actors Guild, for whose members it may fairly be said that fame is an appropriate goal, maintain as an objective of the organization the prevention of duplicate name registration. Thus, each working actor, past, present, and future, is encouraged to register a unique name, building efficiency into a self-regulatory system. Screen Actors Guild Rules and Regulations $\S 15$ (on file with author).

50 Madow, $81 \mathrm{Cal} \mathrm{L} \mathrm{Rev} \mathrm{at} \mathrm{178-79} \mathrm{(cited} \mathrm{in} \mathrm{note} \mathrm{13).} \mathrm{See,} \mathrm{for} \mathrm{example,} \mathrm{Federal} \mathrm{Trademark}$ Act of 1946 ("Lanham Act") $\S 43$ (a), 60 Stat 441, codified at 15 USC § 1125(a)(1) (1994) (creating statutory tort of false representation of goods in commerce).

51 Madow, 81 Cal L Rev at 228 (cited in note 13).

52 Id at 228-29.

53 Douglas G. Baird, Note, Human Cannonballs and the First Amendment: Zacchini v. Scripps-Howard Broadcasting Co., 30 Stan L Rev 1185, 1187 n 7 (1978).

5415 USC § 1114 (1994 \& Supp 1998).
} 
mining the identity of the "speaker" as to at least part of the population of the World Wide Web. This is especially relevant on the Internet, where there is so little guarantee of a speaker's identity. Consumers would also be protected from tricks like being directed to a pornographic web site when trying to access a celebrity's web site. Since the unauthorized use of a celebrity's name as a web site address would be prohibited, a celebrity could prevent another party from making such use of his name.

\section{Moral rationales for the doctrine.}

Finally, there are moral justifications for the doctrine based on the right of people to "reap the fruits of their labors," or to prevent the injustice of allowing others to "reap where they have not sown." "56 Melville Nimmer argues that someone "who ha[s] long and laboriously nurtured the fruit of publicity values," and invested "time, effort, skill, and even money" in their development, deserves to enjoy the benefits himself. Indeed, it is almost axiomatic in American culture that one gets out of something what one puts in; thus any advantage gained from attaining celebrity status should belong to the celebrity, as he is the one who has "worked" to realize his position.

This rationale, like the economic and consumer protection arguments, also maintains its strength when offered to justify extending the right of publicity to the Internet. Since we protect a celebrity's right to "reap the fruit" of his own labor by allowing him to select who or what he endorses in a print, radio or television advertisement, it follows that we would likewise afford the same protection on the Internet. An Internet web site is an easy analogy to an advertisement, since many web sites sell advertising space in the form of banner ads or provide links to other sites. Often, advertising revenue is determined merely by the number of "hits" a web site attracts ("web traffic"), regardless of the length of stay. Thus, a web site operator could register a celebrity's name as its domain name and succeed in attracting a great deal of web traffic due solely to interest in the celebrity.

Affording a celebrity protection in his name as a domain name would prevent web site operators from "reaping where they have not sown": from profiting in advertising revenues or even by merely attracting attention to information on a web site that never would have been accessed but for the use of the celebrity's name. Even noncommercial uses of the web site would injure the celebrity by preventing him from enjoying whatever benefit there was from maintaining a

\footnotetext{
S5 note 44.

6 Madow, 81 Cal L Rev at 178 (cited in note 13).

57 Melville B. Nimmer, The Right of Publicity, 19 L \& Contemp Probs 203, 216 (1954).
} 
web site. The celebrity would also have the opportunity to use his name as a domain name and set up whatever form of web site he chooses to associate with his name, thus allowing him the benefit of his "labor" as a celebrity. Accordingly, the moral justification, along with the economic and consumer protection rationales described above, provides a foundation for courts to extend the right of publicity to the Internet.

\section{B. Obstacles to Applying Publicity Rights Law to Domain Name Disputes}

1. Difficulties presented by the architecture of the Internet.

There is an ongoing debate about whether the Internet can be regulated at all, ${ }^{\$ 8}$ much less governed by publicity rights and other preexisting state law. The challenges posed by Internet regulation include: (a) defining the jurisdictional boundaries of a medium lacking a physical location, and preventing inconsistent enforcement by multiple regulators, and (b) enforcing remedies against virtually anonymous participants.

a) Jurisdictional confusion. Opponents to regulation have said that cyberspace disrupts geographic boundaries and undermines the relationship between law and the physical location of the potential offender. ${ }^{59}$ They argue that the application of geographically based conceptions of legal regulation to activity occurring in the boundariless nether regions of cyberspace either is illogical or will lead to unresolvable confusion. ${ }^{60}$

Critics also contend that because transactions on the Internet occur essentially at the same time everywhere, all jurisdictions could simultaneously attempt to govern such activity, leading to redundant or inconsistent regulation of the same transaction. ${ }^{61}$ They argue that the fluid nature of cyberspace prohibits adequate notice of applicable law, and further will allow Internet transactions to be designed so that un-

58 For general discussions, see Jack L. Goldsmith, Against Cyberanarchy, 65 U Chi L Rev 1199 (1998) (arguing that regulation of cyberspace is feasible and legitimate but not commenting on its merits); James Boyle, Foucalt in Cyberspace: Surveillance, Sovereignty and Hardwired Censors, 66 U Cin L Rev 177 (1997) (casting doubt upon the regulability of the Internet); David R. Johnson and David Post, Law and Borders: The Rise of Law in Cyberspace, 48 Stan L Rev 1367 (1996) (discussing the challenges that the Internet presents to current legal doctrines); Dan $L$. Burk, Federalism in Cyberspace, 28 Conn L Rev 1095 (1996) (discussing the problems of multijurisdictional regulation on the Internet).

59 See, for example, Johnson and Post, 48 Stan L Rev at 1374-77 (cited in note 58).

60 Id.

61 Id at 1370-73. 
desirable regulation can be evaded, making such laws seem illegitimate.

Allowing publicity rights law to govern domain name usage also raises the practical question of whether these rights are limited to the familiar ".com" domain names" or whether the law would apply to other top-level domain names. There are a large number of countryspecific top-level domain names in addition to the familiar U.S.-based top-level domain names. If publicity rights were applied to all toplevel domain names internationally, the potential for international legal conflict could arise. On the other hand, if the application were limited in some way, the value of a celebrity's right could be diminished by inconsistent enforcement arising from courts applying different laws and from different levels of protection being afforded depending on the particular top-level domain name.

b) Unenforceable remedies. Remedies are also particularly difficult to enforce in an intangible forum like the Internet. First it is hard to know against whom to enforce a right, given the ease with which anonymity or impersonation can be achieved in cyberspace. And even if defendants could be identified, the low cost of entry into a medium like the Internet greatly increases the probability that they will be judgment-proof. In addition, injunctions might prove to be particularly challenging to impose. The components required to maintain a web site are so easily moved that potential defendants have the ability to literally vanish into thin air and to continue their infringing ways.

2. Problems with applying state law to the Internet.

Beyond the threshold questions of whether regulation is possible, applying pre-existing state laws of publicity rights to the Internet raises questions involving conflicts of law and forum shopping.

a) Choice-of-law uncertainty. Publicity rights do not exist in all states, and where they do exist, their content is not uniform. Thus, courts facing publicity rights suits must determine what law should govern the suit. Choice-of-law rules in most states dictate that courts must apply the law of the state with the most interest in the litigation. ${ }^{65}$ Most courts follow the Restatement (Second) test or Brainerd Currie's interest analysis in determining choice-of-law issues. ${ }^{66}$ Essentially

62 Id at 1375.

63 See note 46 for a definition of domain names.

64 Other possibilities include .org, net, or a variety of international top-level domain names. See note 46 .

65 See, for example, Restatement (Second) of Conflict of Laws (1971)

66 See Restatement (Second) of Conflict of Laws $\$ 6$ (1971); Brainerd Currie, Notes on Methods and Objectives in the Conflict of Laws, 1959 Duke L J 171, 178, reprinted in Brainerd Currie, Selected Essays on the Conflict of Laws 177, 183-84 (Duke 1963). See also Jeffrey M. 
these approaches look to several factors in considering which state's substantive law to apply. These analyses aim to determine which states have a significant enough interest to deem their law applicable, using factors such as domicile of the parties, citizenship, place of infringement, protection of justified expectations, and certainty, predictability, and uniformity of result. ${ }^{67}$

The Internet, however, is not easily understood in terms of physical boundaries. A web site is maintained physically by a server which in turn obtains access to the World Wide Web via an Internet Service Provider ("ISP"). These may be located in different states from each other and from the persons accessing the web site. Thus, even more confusing questions arise over which law is the correct law to apply. Is it the law of the state in which the person who owns the domain name is domiciled? The state in which the server is maintained? The state where the ISP does business? Traditional choice-of-law analysis with consideration of factors like place of infringement does not easily lend itself to application on the Internet.

There are very few cases that apply choice-of-law analysis to the Internet. Furthermore, most cases that do engage in choice-of-law analysis ignore the difficulties in a true interest analysis involving the Internet, instead opting for more categorical rules adopted directly from the physical world. For instance, in Hitchcock $v$ Woodside Literary Agency, ${ }^{\circledR}$ the district court, applying New York choice-of-law rules, failed to consider how defamation on the Internet might change choice-of-law analysis. The court claimed to apply the law of the place where the plaintiff's injuries occurred, assuming that because the plaintiff lived in and accessed the Internet in Maryland, that is where the harm occurred. ${ }^{69}$ This analysis, however, ignores the complexity of the issue. Because the Internet can be accessed anywhere in the United States, reputational harms may have occurred in many other states," leaving the question of where the injury actually occurred much less clear than the court suggested.

Shaman, The Vicissitudes of Choice of Law: The Restatement (First, Second) and Interest Analysis, 45 Buff L Rev 329 (1997) (arguing that interest analysis is the best way to make choice-of-law decisions); Bruce Posnak, Choice of Law-Interest Analysis: They Still Don't Get It, 40 Wayne L Rev 1121 (1994) (explaining what interest analysis is and stating that its critics often misunderstand the concept); Alfred Hill, The Judicial Function in Choice of Law, 85 Colum L Rev 1585 (1985) (discussing the revolution of choice-of-law rules and why precedent should be followed in this area).

67 Restatement (Second) of Conflict of Laws $\$ 6$ and accompanying comments; Currie, 1959 Duke LJ at 178 (cited in note 66).

68 15 F Supp 2d 246 (E D NY 1998) (dismissing plaintiff's New York common law defamation claims for harmful speech that was disseminated via the Internet after finding, without discussion, that plaintiff's injuries occurred in Maryland, where she was domiciled).

69 Id at 251-52.

70 See Isuzu Motors Ltd v Consumers Union of United States, 12 F Supp 2d 1035, 1044 (C 
Because a court must consider many factors when determining which state is most interested, in any given case many states' laws could apply." Often judges find it difficult to know which state is most interested, and the initial task of determining which law to apply can overwhelm a court and destroy judicial economy. ${ }^{2}$ As a consequence, similar claims may be treated in different ways depending on the forum's choice-of-law analysis.

b) Forum shopping. Applying publicity rights law that is individually codified by state to domain name disputes likely will create incentives for forum shopping, a situation that could potentially eviscerate the effectiveness of various state laws. The Internet could prove to be a veritable mecca for forum shopping, as a party would be able to pick and choose whatever state law he liked the best. Access to a web site in a given jurisdiction may establish the minimum contacts necessary to apply that state's substantive law to the underlying case, because the flexibility typically available in minimum contacts analysis allows the requisite state interest to be established under a low threshold. ${ }^{34}$ Although choice-of-law rules will also affect the ability to forum shop, as noted, uncertain choice-of-law analysis in the Internet context can be manipulated to allow a state to apply its own law. ${ }^{75}$

Further, in many jurisdictions, limits on the exercise of personal jurisdiction will not prevent forum shopping. Although personal jurisdiction limitations usually act as a check on unrestrained forum shopping, courts have found that the accessibility of a web site in a state provides the minimum contacts necessary to establish personal jurisdiction. $^{76}$ This principle is not universal; some courts require that web

D Cal 1998) (noting that damage to reputation is an injury resulting from defamation).

71 For a general discussion, see Larry Kramer, Interest Analysis and the Presumption of Forum Law, 56 U Chi L Rev 1301 (1989).

72 See Zeran v America Online, Inc, 958 F Supp 1124, 1129 n 7 (E D Va 1997) (noting the failure of the parties to raise the difficult choice-of-law issue of "which state's tort law is applicable to an alleged injury caused by an anonymous posting of a bogus message on an interactive computer system operated by a corporation residing in Virginia where the notice is available for review by online subscribers internationally and results in harm to a plaintiff in Washington").

73 Access to a web site in a jurisdiction may satisfy the low minimum contacts standard required for due process limits on choice of law. Compare Home Insurance Co v Dick, 281 US 397 (1930) (describing the due process limits on choice of law).

74 See Keeton v Hustler Magazine, Inc, 131 NH 6, 549 A2d 1187, 1188, 1196 (1988) (holding that state had sufficient interest in suit to apply its law, despite blatant forum shopping and limited distribution of defendant's magazine). Regarding state interests, see Restatement (Second) of Conflict of Laws \$ 6; Currie, 1959 Duke L J at 178 (cited in note 66).

75 See Part II.B.2.a.

76 See, for example, Compuserve, Inc v Patterson, 89 F3d 1257, 1263 (6th Cir 1996) (finding that distributing software on a web site through an ISP based in the forum state was a sufficient basis for jurisdiction); National Football League v Miller, 2000 US Dist LEXIS 3929, *6 (S D NY 2000 ) (holding that jurisdiction over an out-of-state defendant did not violate due process when the defendant's web site damaged the plaintiff and generated substantial profits in the forum state); Stomp, Inc v Neato, LLC, 61 F Supp 2d 1074, 1078 (C D Cal 1999) (finding that marketing 
sites engage in active solicitation ${ }^{n}$ in order to constitute purposeful availment of the state's benefits. ${ }^{78}$ For states that do recognize personal jurisdiction through web site access, the due process limitation on personal jurisdiction is rendered virtually meaningless. This could lead to people being haled into court in virtually any state at the whim of others.

\section{COURTS SHOULD APPLY PUBLICITY RIGHTS LAW TO DOMAIN NAME DISPUTES}

As publicity rights law has developed in various media to protect and preserve the integrity and economic value of celebrity names, it should now be applied to a new medium: domain names. Currently, the domain disputes that have been adjudicated deal with registered marks (for example, www.yourtrademark.com) and utilize trademark law. ${ }^{79}$ Domain name disputes that involve celebrity names, not registered marks, are relatively new phenomena to United States courts. Since these disputes are not governed by trademark law, celebrities need to find some other source of protection for their names. Expanding the scope of publicity rights to include the Internet would be the most logical and judicially practicable solution.

Characteristics peculiar to the structure of the domain name system and publicity rights law remove the obstacles inherent in regulating a boundariless medium like the Internet. ${ }^{80}$ Domain names, unlike other areas of the Internet, are particularly well suited for regulation, as illustrated by the cases already applying trademark law to domain name disputes. Moreover, the nature of publicity rights law itself makes it particularly well suited to regulating celebrity domain name disputes because publicity rights law provides clear limitations about

through a web site constitutes sufficient minimum contacts to warrant exercise of personal jurisdiction in suit challenging validity of patent); Heroes, Inc v Heroes Foundation, 958 F Supp 1, 3 (D DC 1996) (holding that knowingly advertising on a web site and receiving publicity and contributions subjects one to jurisdiction).

77 See, for example, Maritz, Inc v Cybergold, Inc, 947 F Supp 1328, 1334 (E D Mo 1996) (finding that a web site's infringement on a trademark is a basis for jurisdiction in the state given active solicitation of citizens in that state); Bensusan Restaurant Corp v King, 937 F Supp 295, 301 (S D NY 1996) (holding that simply creating a web site that can be accessed in New York, without actively soliciting in New York, does not subject defendant to personal jurisdiction in New York); McDonough v Fallon McElligott, Inc, 40 USPQ2d 1826, 1830 (S D Cal 1996) (finding that a web site must be "specifically directed" towards the forum state in order to subject the site owner to personal jurisdiction).

78 Purposeful availment of a state's benefits fulfills the due process limitation on personal jurisdiction. Hanson v Denckla, 357 US 235, 253 (1958). See also International Shoe v Washington, 326 US 310 (1945) (holding that systematic and continuous contact with the state was sufficient to establish personal jurisdiction).

79 For discussion of how trademark law is applied, see note 83 and accompanying text.

80 See Part II.B. 
who may exercise the right, and celebrities make up a small proportion of Internet users. This Part first demonstrates by analogy to trademark law how domain name disputes on the Internet can be regulated; then it addresses the choice-of-law and forum shopping issues, where the analogy is inapt because publicity rights law does not exist in a uniform federal scheme like trademark law.

\section{A. Analogizing Domain Name Disputes to Trademark Disputes Demonstrates that Domain Names Can Be Regulated}

The architecture of the domain name system has been designed such that every domain name is globally unique. One acquires the right to use a particular domain name by registering that name with an authorized administrator of the central database of names, such as Network Solutions, Inc. ("NSI"), and paying the initial registration fee and subsequent renewal fees, which are typically biannual. Once a domain name has been registered, it is unavailable for use by any other party in the world. When a party attempting to register a name discovers that it is already in use, and he believes that for some reason he has a superior right to use that domain name, he can initiate legal action against the party who registered the domain name.

Domain name disputes can and have been regulated by trademark law. ${ }^{81}$ The fact that trademark law mandates an affirmative duty to register in order to attain rights in a mark limits who has rights to use a trademark as a domain name. This registration requirement is analogous to the strict restrictions in publicity rights law on the type of name that merits protection. By looking at cases involving trademark disputes, the difficulties of jurisdictional confusion, inconsistent regulation, and absence of remedies may appear more easily resolved in the context of publicity rights on the Internet than first anticipated.

81 See note 83. For a more extensive discussion, see Swartz, Comment, 45 UCLA L Rev at 1487 (cited in note 46) (analyzing the application of trademark law to domain name disputes and concluding that a new cause of action should be created to deal with the problem); Ira Nathenson, Comment, Showdown at the Domain Name Corral: Property Rights and Personal Jurisdiction over Squatters, Poachers and Other Parasites, 58 U Pitt L Rev 911, 989 (1997) (concluding that "[t] he Lanham Act provides a good, [but] flawed, analytical framework for settling domain name disputes"). See also Marguerite S. Dougherty, Note, The Lanham Act Keeping Pace With Technology, 7 J L \& Pol 455 (1999) (arguing that Congress should "provide for nationwide jurisdiction in trademark controversies [that are] derived from electronic contacts on the Internet").

82 Depending upon geographic distance and differentiation in industry, multiple parties may own rights in the same mark, so that there is not necessarily a monopoly in a particular mark. However, registration of a mark is limited by the overriding concern for preventing consumer confusion. A mark may not be registered by multiple parties if there is a likelihood that consumers would be confused as to the product's origin. 15 USC $\$ 1052$ (1994 \& Supp 1998). 
1. Avoiding inconsistent regulation.

Despite the concerns raised above regarding the jurisdictional confusion caused by regulating the Internet, trademark law has been successfully utilized to adjudicate a number of domain name disputes involving marks. ${ }^{83}$ Courts apply the same analysis developed in nonInternet trademark cases to Internet domain name disputes involving registered marks, thus providing precedent for extending an existing intellectual property right onto the Internet. Most claims for trademark infringement in domain name controversies arise in cases in which domain name owners incorporate the trademark holder's exact mark, or an extremely close version of the mark, into a domain name. Extending publicity rights to domain names would simply provide celebrities with a right to a similar claim. Thus, domain name cases under trademark law are indicative of the types of cases that will arise if publicity rights law is extended to the Internet and demonstrate that regulating the Internet is not impossible.

This is so because domain names are very similar to trademarks on the Internet. Like the monopoly that trademark holders enjoy, domain name owners possess discrete monopolies. Regardless of the number of mark holders or celebrity rights claimants, for better or worse, the architecture of the World Wide Web dictates that only one person can claim a monopoly over a particular domain name. Even in trademark law, where two people can own rights in the same mark, as long as they are in different industries or significantly distant geographic locations, only one person can have that mark name as a do-

83 Two primary types of cases arise under trademark law as applied to Internet domain name disputes: "domain name grabbing" and "reverse hijacking" cases. Domain name grabbing cases involve individuals known as "cyber-squatters" or "parasites" who strategically register trademarks as domain names either to sell them to the federally registered trademark holders or to keep the domain names from the trademark owners. In reverse highjacking cases, domain name registrants may unknowingly register another's trademark or may themselves have legitimate rights in the trademark, but the actual trademark holder seeks to "reverse hijack" in order to gain control over the use of the domain name through NSI or the courts. See note 44 for a description of recent "domain name grabbing" cases, in which plaintiffs routinely triumph in suits against cyber-squatters. Precedent also sways in favor of the trademark plaintiff in reverse hijacking cases. See, for example, Cardservice International, Inc v McGee, $950 \mathrm{~F}$ Supp 737, 740-41 (E D Va 1997) (ordering defendant to relinquish "cardservice.com" web site used to market credit and debit card processing services due to likely confusion with plaintiff's identical services sold under the registered mark "Cardservice International"); Planned Parenthood Federation of America, Inc v Bucci, 42 USPQ2d 1430 (S D NY 1997) (holding for plaintiff where defendant registered domain name "plannedparenthood.com" to identify a web site promoting an antiabortion book). See also ActMedia, Inc v Active Media International, Inc, 1996 US Dist LEXIS 20814, *3 (N D Il) (finding defendant's use of domain name "actmedia.com" precluded plaintiff from reserving the domain name incorporating its registered mark and therefore violated 15 USC $\$ 1125$ (1994)). For a general discussion, see Dougherty, Note, 7 J L \& Pol 455 (cited in note 81); Swartz, Comment, 45 UCLA L Rev 1487 (cited in note 46); Nathenson, Comment, 58 U Pitt L Rev 911 (cited in note 81). 
main name on the Internet. Thus, the party with rights to the mark trumps a party without rights, and the first party with rights to register the domain name attains monopoly rights over that domain name." Similarly in publicity rights, although there is no formal registration, a celebrity's rights in his name may trump an ordinary person's rights, even if they share identical names. This is true even if the ordinary person was not using the web site for any commercial gain because preventing the celebrity from using his name deprives him of a valuable commodity, and, though it may be an unintentional effect, may dilute the celebrity's name, damaging its commercial value. ${ }^{35}$ In the unlikely event that two celebrities share the same name, the first celebrity to register that domain name would trump.

\section{Enforcing remedies.}

Finally, unlike other aspects of the Internet, the nature of the domain name system is well suited to enforcing legal remedies, particularly with regard to those available under publicity rights law. The domain name system requires every web site operator to register and pay a fee in order to attain a specific domain name. Potential defendants are therefore easily identified. In addition, a renewal fee must be paid typically every two years. Thus, rights to a domain name resemble a landlord/tenant relationship, where the landlord retains significant control over his property. Infringement of a celebrity's publicity rights caused by the use of a particular domain name can be remedied easily by taking away the infringer's rights to that domain name and allowing the celebrity to take control of the web site name. A domain name, as a piece of property, could be seized in an in rem action in those cases where the party that registered the domain name can-

\footnotetext{
84 See notes 45 and 83.

85 See McCarthy, The Rights of Publicity and Privacy $\$ 3.1$ at 3-3 (cited in note 6).

86 Even though attaining control of a domain name does confer a worldwide monopoly, the application of publicity rights law to domain names can be fashioned to avoid impinging upon the laws of other nations. Although domain names exist internationally, the top-level domain name does provide a way to differentiate by country, such as .uk for the United Kingdom, .ger for Germany, and so forth. The application of publicity rights law could be restricted to familiar U.S. domain names-those that are available for public use, .com, .org, and net-thus cabining complete international application. Because country-specific top-level domain names are significantly less familiar to the American public than U.S.-specific ones such as .com or .org, the threat of dilution or unjust enrichment from such foreign use is not as great in the United States, and activity abroad is not a primary concern of U.S. courts.

This scheme would sufficiently protect a celebrity's value in his name, as it appropriately balances preventing the dilution of a celebrity's name against extending state law into an international forum. Furthermore, the simple fact that U.S. courts would be unable to provide absolute protection from all infringement does not mean that the courts should not uphold state publicity rights laws and afford celebrities the best possible protection within the realm of U.S. top-Ievel domain names.
} 
not be located. This simple scheme of enforcement provides further support for the application of publicity rights law to celebrity domain name disputes.

B. Conflict of Laws and Forum Shopping as a Vehicle for the Application of Uniform Publicity Rights to Domain Names

Because publicity rights law is state law, its application to domain name disputes is considerably more complicated than that of trademark law. The application of publicity rights law must overcome the conflict of laws and forum shopping problems detailed above. In this respect, trademark law is not an apt analogy because it is federal law, and therefore these problems do not arise.

\section{Choice-of-law determinations.}

Choice-of-law determinations are challenging because they are complex and expend judicial resources. The first step in analyzing a publicity rights claim in a domain name dispute is determining the state law that applies. Specific choice-of-law rules depend upon the state in which the lawsuit is filed. Factors normally taken into account in publicity rights disputes such as domicile and state interest, among others, are still cognizable. Because of the boundariless quality of the Internet, the location of infringement does become less straightforward in the analysis. But as long as courts establish clear criteria to consider when analyzing choice-of-law questions pertaining to the Internet, applying publicity rights law to domain name disputes remains theoretically feasible. In actual application, choice-of-law principles, especially with regard to the Internet, are generally flexible enough to allow states that already have jurisdiction to apply their own law, and most states prefer to do so. ${ }^{80}$ Thus, a party could affect the choice of law by choosing to sue in a certain jurisdiction, as the likelihood is that the forum will apply its own law.

Although courts are nominally limited by Due Process and Full Faith and Credit considerations in choice-of-law decisions, in reality these considerations place few limits on courts' choices." As a consequence, so long as there is some interest for a state to apply its laws,

87 See Part II.B.2.

88 See Goldsmith, 65 U Chi L Rev at 1232-37 (cited in note 58) (arguing that choice-of-law problems in cyberspace are not very different from those in the physical world context).

89 See Kramer, $56 \mathrm{U}$ Chi L Rev 1301 (cited in note 71). See also Rosenthal $v$ Fonda, 862 F2d 1398, 1402 (9th Cir 1988) ("As the forum, a California court will conclude that a conflict is 'false' and apply its own law unless the application of the foreign law will 'significantly advance the interests of the foreign state."') (citation omitted).

90 See Keeton $v$ Hustler, 131 NH 6, 549 A2d 1187, 1196 (1988). See also text accompanying note 74. 
the Constitution places no further limits. Applying this analysis to the Internet publicity rights context, most fora will have no constitutional problem applying their own law. Furthermore, choice-of-law principles suggest that every state has an interest in the litigation, because web sites are accessible from every state. Even if neither party is domiciled in the state, the state has an interest in protecting its consumers from misleading web sites." Thus, a state can also claim itself as the place of injury, a cognizable factor in choice-of-law analysis, where dilution constitutes the harm. Even if the celebrity plaintiff is not domiciled in a particular state, the value of his name can still be damaged wherever his reputation exists. Given the preference of most state courts for applying their own law, ${ }^{92}$ and the fact that they have a cognizable interest in the litigation, in the Internet context, a forum can apply its own law.

\section{The benefit of forum shopping.}

Similarly, forum shopping does not necessarily present an insurmountable obstacle. In fact, in the case of applying publicity rights to domain name disputes, forum shopping would likely effectuate a beneficial result - uniform national law. Publicity rights disputes, more than other types of claims, are particularly predisposed to such an outcome. Plaintiffs seeking to enforce their publicity rights in these disputes would, by definition, be celebrities. Since celebrities tend to have a great deal of resources at their disposal, these plaintiffs would have the ability to forum shop by suing in states providing the most protection for their persona, hoping that the forum state would choose to apply its own law. This push to apply the most favorable law could create a de facto national law as applied to the Internet, resulting in uniform adjudication of celebrity domain name disputes.

Although this essentially eviscerates individual state publicity rights law with respect to domain names, it solves the problem of notice by creating a uniform national standard. While some might argue that this is an impermissible interference with state sovereignty, states that have not chosen to protect celebrities will not have their courts commandeered; celebrities will be forced to enforce their rights in states that do provide protection. Also, since the web is accessible in every state at once, and regulation of the web affects every jurisdiction's access to the web's content, the web is necessarily suited to uniform regulation and uniquely removed from the justifications for preserving state sovereignty.

Furthermore, in order to achieve the efficient level of protection of the publicity rights of celebrities, state law should not create exter-

91 This assumes that a state enacts laws to protect its citizens.

92 See text accompanying notes $88-91$. 
nalities that allow citizens of a state to reap benefits at the expense of celebrities in other states, or vice versa. For example, states without a significant number of celebrities ${ }^{93}$ are unlikely to enact legislation or recognize a common law right that protects celebrities' rights over the rights of their own citizens. These states, however, also benefit from celebrities who bring publicity rights actions to protect the use of their name, because citizens of those states enjoy the cultural benefits such as films and sports events that those celebrities create. Thus, applying publicity rights to domain names and allowing celebrities to forum shop is a way to provide regulation with appropriate incentives. ${ }^{4 n}$ addition, one of the primary goals of the choice-of-law doctrine is to promote uniformity, and this result achieves that goal.

\section{CONCLUSION}

Publicity rights law should offer the same protection in cyberspace that it affords in tangible space. The border-transcending nature of the Internet and its fluid form require publicity rights law that will likewise transcend boundaries. Recognizing a right of publicity as applied to domain names would provide that necessary protection, and create consistency and certainty in the law.

93 Note that those states that have not enacted publicity rights legislation or recognized a common law right of publicity are not known for generating a large number of celebrities, while the first states with publicity rights protections were California and New York-states populated by many celebrities. See notes 3,8-13 and accompanying text.

94 It could be argued that allowing celebrities to forum shop will lead to excessively procelebrity publicity rights law, because some states with a lot of celebrities will have laws that excessively protect the interests of their celebrity-citizens at the expense of non-celebrities in other states. However, if celebrities are allowed to forum shop, they need not reside in those states in order to gain the benefits of their favorable publicity rights laws. Thus, states with inefficient procelebrity laws will bear the costs of the litigation attracted to their courts without guaranteeing that celebrities will reside within their borders. 


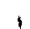

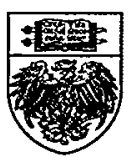

